Article

\title{
Redox-Responsive Coordination Polymers of Dopamine-Modified Hyaluronic Acid with Copper and 6-Mercaptopurine for Targeted Drug Delivery and Improvement of Anticancer Activity against Cancer Cells
}

\author{
Bo Tao and Zongning Yin * \\ Key Laboratory of Drug Targeting and Drug Delivery Systems, West China School of Pharmacy, \\ Sichuan University, No. 17, Block 3, Southern Renmin Road, Chengdu 610041, China; apharmacy@163.com \\ * Correspondence: yzn@scu.edu.cn; Tel./Fax: +86-28-85502917
}

Received: 11 April 2020; Accepted: 8 May 2020; Published: 14 May 2020

check for updates

\begin{abstract}
Dopamine-modified hyaluronic acid (HA-DOP) was chosen as the drug carrier in this study, and $\mathrm{Cu}^{2+}$ was selected from among $\mathrm{Cu}^{2+}, \mathrm{Zn}^{2+}, \mathrm{Fe}^{2+}$, and $\mathrm{Ca}^{2+}$ as the central atom. 6-Mercaptopurine (6-MP) was conjugated with HA through a coordination reaction. HA-DOP-copper-MP (HA-DOP-Cu-MP), a redox-responsive coordination polymer prodrug, was prepared. The drug loading was $49.5 \mathrm{mg} / \mathrm{g}$, the encapsulation efficiency was $70.18 \%$, and the particle size was $173.5 \mathrm{~nm}$. HA-DOP-Cu-MP released rapidly in the release medium containing reduced glutathione (GSH), and the accumulated release exceeded $94 \%$ in $2 \mathrm{~h}$. In the release medium without GSH, the drug release rate was slow, with only $15 \%$ of the 6-MP released in $24 \mathrm{~h}$. Cell uptake experiments revealed the CD44 targeting of HA. Cell viability assays showed that the cytotoxicity of HA-DOP-Cu-MP was higher than that of free 6-MP. Indeed, HA-DOP-Cu-MP is very toxic to cancer cells. In this paper, the redox-responsive drug delivery system was synthesized by a coordination reaction. The tumour targeting and tumour cytotoxicity of 6-MP were improved.
\end{abstract}

Keywords: coordination; hyaluronic acid; 6-Mercaptopurine; redox-responsive; targeting

\section{Introduction}

Cancer is the primary cause of morbidity and mortality worldwide. The pharmaceutical industry has invented many cytotoxic drugs that could potentially cure cancer. Unfortunately, these drugs also have enormous systemic toxicity to normal tissue. Polymers and polymeric microparticles drug delivery systems can improve solubility, prolong drug release time, and enhance targeting of many drugs [1-6]. The new generation of multifunctional nanodrug delivery systems can release drugs after stimulation, such as $\mathrm{pH}$, temperature, redox, magnetic or electrical field, light, pressure, ultrasound, enzymes, and glucose stimulation $[7,8]$.

Most stimuli-responsive carriers release drugs by breaking chemical bonds, such as hydrazine [9], oxime [10], azo [11], or disulfide bonds [12]. Recently, researchers found that drugs could also be released by breaking coordination bonds. The relevant complexes are composed of central atoms (M, metal) and ligands (L, ligand). Coordination chemistry constitutes the bridge between organic chemistry and inorganic chemistry. Complexes have many bonding modes and structural types. A variety of materials with special functions can be synthesized through coordination reactions, such as conductive functional complexes, luminescent functional complexes, magnetic functional complexes, and complex porous materials. $\mathrm{Gd}^{3+}, \mathrm{Fe}^{3+}$, and $\mathrm{Mn}^{2+}$ complexes can be used as contrast 
agents for nuclear magnetic resonance (NMR) imaging in medicine [13]. The cisplatin $\left(\mathrm{PtCl}_{2}\left(\mathrm{NH}_{3}\right)\right.$ 2) metal complex is used to treat cancer [14]. The complexation of a drug and a metal improves the water solubility of insoluble drugs [15]. Additionally, the use of such complexes reduces the toxic side effects and releases the drugs only under certain conditions, such as low $\mathrm{pH}$ [16], enzymes [17], redox [18], and light [19]. Indeed, complex prodrugs synthesized from metals and drugs have attractive prospects $[20,21]$.

The coordination ability of the groups of many delivery vehicles is weak, making it difficult to form complexes with drugs. Mussels provide a solution to this problem. Mussels can adhere to reefs, ships, and even paraffin and Teflon. Mussels secrete a type of adhesive protein that contains dopamine, which is the key to mussels' superior adhesive capacity [22]. Dopamine is widely distributed in the human body and is an important neurotransmitter [23]. The two phenolic hydroxyl groups of dopamine form stable complexes with some metal ions. The strength of the bonds between dopamine and metal ions $(0.8 \mathrm{nN})$ is similar to the typical strength of a covalent bond $(2 \mathrm{nN})$ [24]. This characteristic is why dopamine is widely used to modify polymers for drug delivery, such as poly (ethylene glycol) (PEG), chitosan, mesoporous silica, and hyaluronic acid (HA). Indeed, dopamine is an ideal ligand.

$\mathrm{HA}$ is an anionic linear polysaccharide consisting of repeats of two sugar units: D-glucuronic acid and $N$-acetyl glucosamine $[25,26]$. HA is a major component of the extracellular matrix and can bind to receptors, such as hyaluronan-mediated motility receptor (RHAMM), CD44, lymphatic vessel endothelial hyaluronan receptor 1 (LYVE-1), liver-expressed chemokine (LEC), Toll-like receptor 4 (TLR4), hyaluronan receptor for endocytosis (HARE), and tumour necrosis factor-inducible gene 6 (TSG6) $[27,28]$. Most tumour cells, such as liver cancer, breast cancer, melanoma, and colon cancer cells, highly express the CD44 receptor. The CD44 receptor can bind to HA oligosaccharide units with as few as four monosaccharides [29], indicating that HA has a strong ability to bind to CD44. Therefore, $\mathrm{HA}$ is an excellent tumour-targeting vector and is widely used in polymer drug delivery systems [30].

6-Mercaptopurine (6-MP) is a purine antagonist chemotherapeutic drug and immunosuppressive agent. It is usually used to treat a variety of diseases, such as acute lymphoblastic leukaemia, malignant lymphoma, multiple myeloma, chorionic epithelial cell carcinoma, rheumatoid arthritis, and enteritis. It is also used to prevent rejection after organ transplantation [31-33]. The solubility of 6-MP in water is low, and this compound is only soluble in sodium hydroxide solution or organic solvents, such as dimethyl sulfoxide (DMSO). Free thiol readily combines with plasma protein to form disulfide bonds. 6-MP has the shortcomings of systemic toxic side effects, a short half-life, low bioavailability, and gastrointestinal reactions after oral administration [34].

To avoid these shortcomings and increase the water solubility and efficacy of 6-MP, we chose HA as the carrier and modified it with dopamine to enhance its coordination ability. HA-dopamine-copper-MP (HA-DOP-Cu-MP) was synthesized via a coordination reaction (Figure 1). Redox reactions are ubiquitous in cells and play an important role in the process of cell metabolism. Reactive oxygen species (ROS) such as $\mathrm{H}_{2} \mathrm{O}_{2}$ and $\mathrm{NO}$ can impair normal cell function. When the concentration of ROS in the cell is too high, in order to react with too much ROS, 5 to $10 \mathrm{mM}$ glutathione (GSH) is usually present in healthy cells [35]. Compared with normal cells, cancer cells exhibit sustained metabolic oxidative stress, mainly owing to inherent mitochondrial dysfunction and NOX activation. As part of metabolic reactions, high levels of ROS are produced [36], so the content of glutathione in tumor cells is higher. For example, the GSH concentration in A549 cells is seven times higher than that in healthy cells $[37,38]$. Thus, intracellular GSH can be used as a stimulating signal. Blood vessels in tumor tissue are more permeable than healthy tissue, and nanoparticles can penetrate through these gaps. In addition, there is no lymphatic drainage in tumor tissue, and nanoparticles can selectively accumulate in tumor $[39,40]$. When the HA-DOP-Cu-MP coordination polymer was internalized by tumour cells, 6-MP was released in the presence of GSH, killing the tumour cells (Figure 2). 
(A)

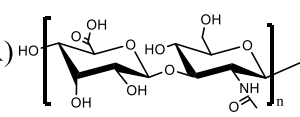

HA

(B)

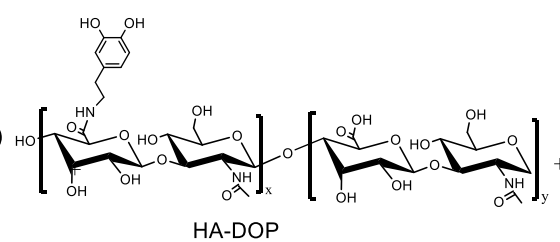

HA-DOP
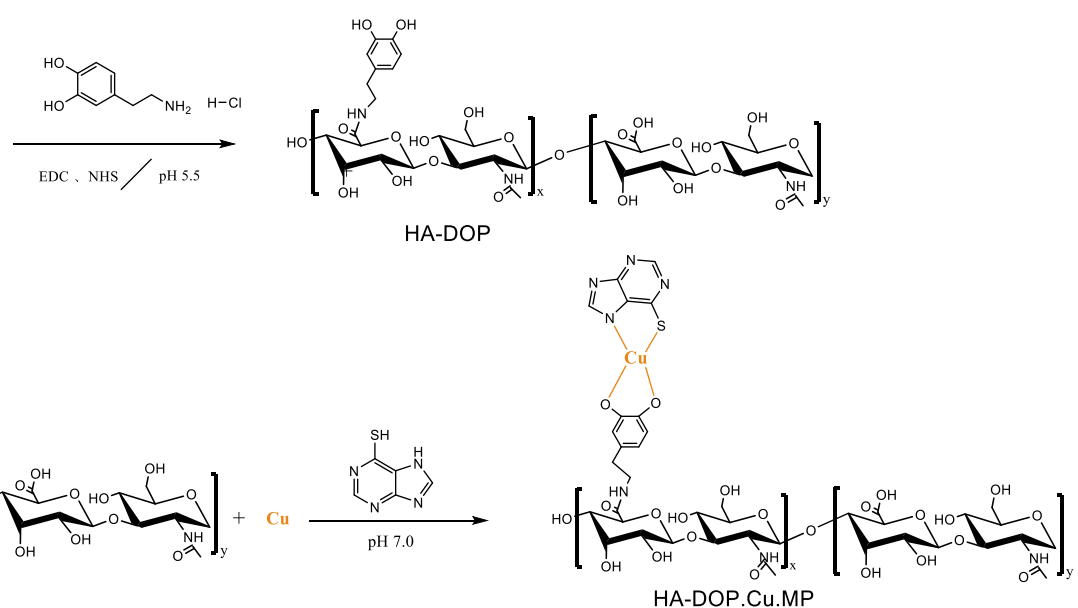

Figure 1. (A) Synthesis scheme of dopamine-modified hyaluronic acid (HA-DOP) via 1-(3-Dimethylaminopropyl)-3-ethylcarbodiimide hydrochloride/ $N$-hydroxysuccinimide (EDC/NHS) coupling chemistry. (B) Synthesis scheme of HA-DOP-Cu-MP coordination polymers via a coordination reaction.
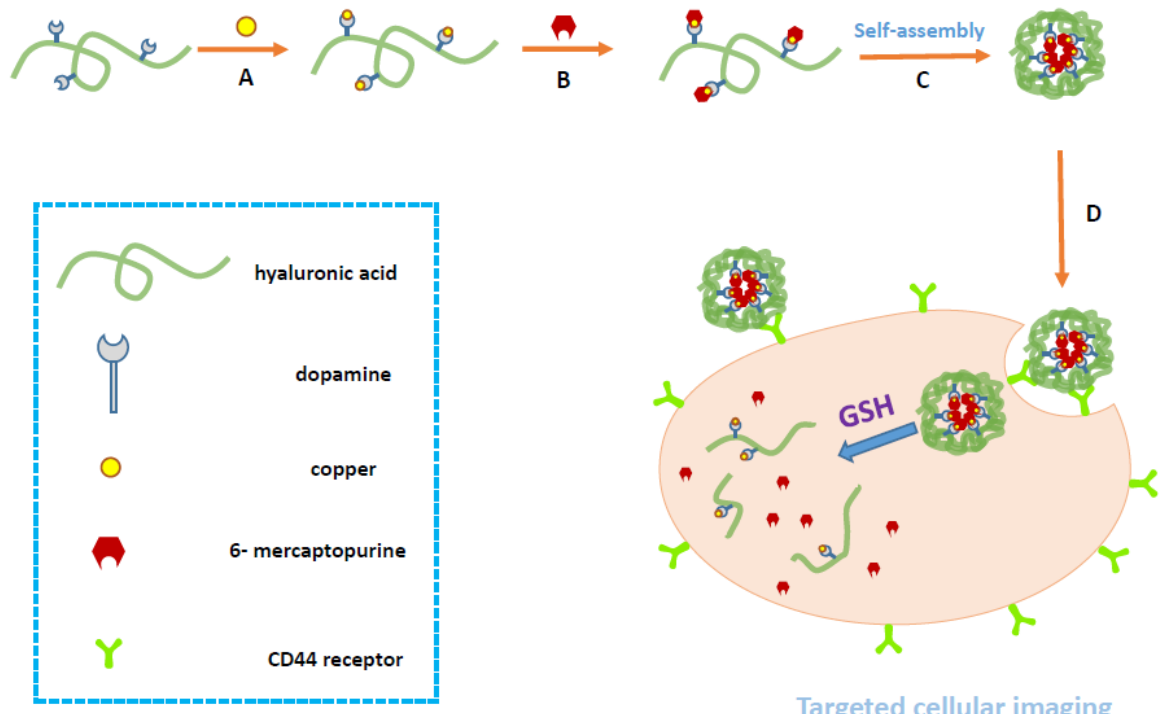

Targeted cellular imaging

Figure 2. Schematic illustration of the synthesis, self-assembly, and intracellular trafficking pathway of HA-DOP-Cu-MP coordination polymer nanoparticles. The intracellular trafficking pathway includes receptor-mediated endocytosis, reduction-triggered coordination polymer nanoparticle disassembly, and drug release. GSH, glutathione.

\section{Experimental}

\subsection{Materials}

Sodium hyaluronate (molecular weight: $5 \mathrm{kDa}$ ) was purchased from Bloomage Freda Biopharm Co. Ltd. (Jinan, Shandong, China). 1-(3-Dimethylaminopropyl)-3-ethylcarbodiimide hydrochloride (EDC), $\mathrm{N}$-hydroxysuccinimide (NHS), cystamine hydrochloride, fluorescein isothiocyanate isomer I (FITC), glutathione, and 6-MP were purchased from Aladdin Chemical Reagent Co., Ltd. (Shanghai, China). Cystamine dihydrochloride, dopamine hydrochloride, and 1,6-hexanediamine dihydrochloride were purchased from Bide Pharmatech Co., Ltd. (Shanghai, China). The A549 cell line was a generous gift from the Key Laboratory of Drug Targeting and Drug Delivery Systems (West China School of Pharmacy, Sichuan University, Chengdu, China). The NIH/3T3 cell line was kindly provided by Stem Cell Bank (Chinese Academy of Sciences, Shanghai, China). The RPMI1640 medium 
and penicillin-streptomycin liquid were purchased from HyClone Co. Ltd. (South Logan, UT, USA). Dulbecco's modified Eagle's medium (DMEM) was purchased from GIBCO. (Waltham, MA, USA). Foetal bovine serum (FBS) was purchased from FMG Biotech Co. Ltd. (ShangHai, China). 3-(4,5-Dimethylthiazol-2-yl)-2,5-diphenyltetrazolium bromide (MTT) was purchased from Amresco, (Solon, OH, USA). and pancreatin was purchased from Sigma-Aldrich (Shanghai, China).

\subsection{Methods}

\subsubsection{Synthesis of HA-DOP}

HA (0.1 g) was dissolved in $8 \mathrm{~mL}$ of 4-morpholineethanesulfonic acid (MES, pH 6.0) buffer solution, and the $\mathrm{pH}$ was adjusted to 4.7. EDC $(0.24 \mathrm{~g})$ and NHS $(0.12 \mathrm{~g})$ were dissolved in the solution, and the $\mathrm{pH}$ was adjusted to 5.7. After incubation for $15 \mathrm{~min}$, dopamine hydrochloride $(0.47 \mathrm{~g})$ was dissolved in the reaction solution and mixed under magnetic stirring for $3 \mathrm{~h}$. The reaction mixture was purified by dialysis (molecular weight cut-off (MWCO): 3000) against deionized water for $12 \mathrm{~h}$. The dialysis treatment was repeated four times. Finally, HA-DOP was isolated by freeze-drying and kept in a desiccator until use.

\subsubsection{Synthesis of HA-1,6-Hexanediamine dihydrochloride (HA-HDA)}

HA $(0.3 \mathrm{~g})$ was dissolved in $24 \mathrm{~mL}$ of MES ( $\mathrm{pH}$ 6.0). After stirring for $2 \mathrm{~h}$, the $\mathrm{pH}$ was adjusted to 4.7. EDC $(0.72 \mathrm{~g})$ and NHS $(0.35 \mathrm{~g})$ were dissolved in the solution, and the $\mathrm{pH}$ was adjusted to 5.7. After incubation for $15 \mathrm{~min}, 2.84 \mathrm{~g}$ of HDA was dissolved in the reaction system and mixed under magnetic stirring for $5 \mathrm{~h}$. The reaction mixture was purified by dialysis (MWCO: 3000) against deionized water for $12 \mathrm{~h}$. The dialysis treatment was repeated four times. Finally, HA-HDA was isolated by freeze-drying and kept in a desiccator until use.

2.2.3. Study of the Coordinating Abilities of $\mathrm{Cu}^{2+}, \mathrm{Zn}^{2+}, \mathrm{Fe}^{2+}$, and $\mathrm{Ca}^{2+}$ with 6-MP

Stock solutions $(50 \mathrm{mM})$ of $\mathrm{Cu}^{2+}, \mathrm{Zn}^{2+}, \mathrm{Fe}^{3+}$, and $\mathrm{Ca}^{2+}$ were prepared by dissolving $\mathrm{Cu}\left(\mathrm{NO}_{3}\right)_{2} \cdot 3 \mathrm{H}_{2} \mathrm{O}, \mathrm{ZnCl}_{2}, \mathrm{FeSO}_{4} \cdot 7 \mathrm{H}_{2} \mathrm{O}$, and $\mathrm{CaSO}_{4}$ in water, respectively. Then, the 6-MP solution $(50 \mathrm{mM})$ was dispersed in each stock solution to observe whether any precipitate was generated.

\subsubsection{Study of the Stability of HA Derivatives Coordinated with $\mathrm{Cu}^{2+}$ and 6-MP}

The reaction solution $(5 \mathrm{mg} / \mathrm{mL})$ was prepared by dissolving HA, HA-HDA, or HA-DOP in water. A solution of $\mathrm{Cu}\left(\mathrm{NO}_{3}\right)_{2}$ in ethanol was added to the reaction solution, and the $\mathrm{pH}$ was adjusted to 7.0. Then, 6-MP in ethanol $(1 \mathrm{mg} / \mathrm{mL})$ was added to the reaction solution to observe whether precipitation appeared after standing for $12 \mathrm{~h}$.

\subsection{Drug Loading, Entrapment Efficiency, and Solubilization Properties of HA-DOP-Cu-MP}

6-MP content in HA-DOP-Cu-MP. HA-DOP $(200 \mathrm{mg})$ was dissolved in $40 \mathrm{~mL}$ water. A solution of $\mathrm{Cu}\left(\mathrm{NO}_{3}\right)_{2}\left(24 \mathrm{mg} \mathrm{Cu}(\mathrm{NO} 3)_{2} \cdot 3 \mathrm{H}_{2} \mathrm{O}\right.$, dissolved in $12 \mathrm{~mL}$ ethanol solution) was added to the reaction solution, and the $\mathrm{pH}$ was adjusted to 7.0. Then, a solution of 6-MP (17 mg 6-MP. $\mathrm{H}_{2} \mathrm{O}$, dissolved in $17 \mathrm{~mL}$ ethanol solution) was added to the HA-DOP solution, followed by a $12 \mathrm{~h}$ incubation at $23^{\circ} \mathrm{C}$. The resulting conjugate was dialyzed seven times against deionized water, and HA-DOP-Cu-MP was obtained by freeze-drying. HA-DOP-Cu-MP $(5 \mathrm{mg})$ was dissolved in water $(10 \mathrm{~mL})$ to generate the mother liquor. Potassium dihydrogen phosphate buffer $(0.35 \mathrm{~mL}, \mathrm{pH} 7.4)$, potassium permanganate solution $(1.5 \mathrm{~mL}, 1 \mathrm{mM}), \mathrm{NaOH}$ solution $(0.8 \mathrm{~mL}, 1 \mathrm{M})$, and deionized water $(2.2 \mathrm{~mL})$ were added sequentially to $0.15 \mathrm{~mL}$ of the mother liquor. After incubation for $48 \mathrm{~h}$, the fluorescence signal of the final reaction mixture was monitored. The excitation wavelength was $286 \mathrm{~nm}$, and the emission wavelength 
was $397 \mathrm{~nm}$. The content of 6-MP in the solution was calculated according to the fluorescence intensity. The drug loading and entrapment efficiency were calculated based on the content of 6-MP.

$$
\begin{aligned}
& \text { Drug Loading }(\mathrm{DL})=\frac{\text { The content of } 6-\mathrm{MP} \text { in HA }- \text { DOP.Cu.MP }}{\text { The weight of HA - DOP.Cu.MP }} \times 100 \% \\
& \text { Entrapment Efficiency }(\mathrm{EE})=\frac{\text { Actual drug loading }}{\text { Theoretical drug loading }} \times 100 \%
\end{aligned}
$$

Determination of the solubility of 6-MP in aqueous solution. 6-MP $(3.0 \mathrm{mg})$ was dissolved in water $\left(3 \mathrm{~mL}, 37^{\circ} \mathrm{C}\right)$ at a rotating speed of $100 \mathrm{r} / \mathrm{min}$. After being held in a water bath for $72 \mathrm{~h}$ and then centrifuged at 10,000 rpm for $3 \mathrm{~min}$, the supernatant was diluted and measured at $323 \mathrm{~nm}$ on a UV-vis spectrophotometer.

Study of the solubilization of 6-MP by the coordination polymer. HA-DOP-Cu-MP was dissolved in water. Then, the solubility of 6-MP was calculated based on the amount of HA-DOP-Cu-MP in the water.

\subsection{Characterization of $H A-D O P-C u-M P$}

\subsubsection{Particle Size Measurements of HA-DOP-Cu-MP}

HA-DOP-Cu-MP was dissolved in phosphate-buffered saline (PBS) (pH 7.4), and the particle size was measured by dynamic light scattering (Zetasizer Nano ZS90, Malvern, Malvern, UK).

\subsubsection{Characterization of the ${ }^{1} \mathrm{H}-\mathrm{NMR}$ Spectrum}

The sample was dissolved in $0.5 \mathrm{~mL}$ of deuterium oxide. The ${ }^{1} \mathrm{H}-\mathrm{NMR}$ spectra were recorded on a $400 \mathrm{MHz}$ NMR spectrometer (Bruker AVANCE III 400 NMR spectrometer, Bruker, Billerica, MA, USA).

\subsubsection{Fourier Transform Infrared (FT-IR) Spectroscopy}

HA-DOP-Cu-MP or 6-MP was ground with $\mathrm{KBr}$ and pressed to form disks, which were then analysed by FT-IR spectroscopy (Nicolet MAG-560, Thermo, Waltham, MA, USA).

\subsubsection{X-Ray Diffraction (XRD) Spectroscopy}

The XRD spectra of HA-DOP-Cu-MP and 6-MP. $\mathrm{H}_{2} \mathrm{O}$ were collected using an X-ray diffractometer

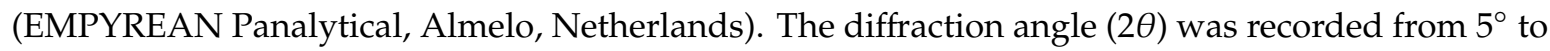
$60^{\circ}$ with a step width of $0.025^{\circ}$, and $\mathrm{Cu}$ was used as the source of X-ray radiation at $40 \mathrm{kV}$.

\subsection{Drug Release Experiment}

The in vitro drug release rate of MP from HA-DOP-Cu-MP was investigated using a dialysis method. The HA-DOP-Cu-MP (7 mg) was dissolved in $5 \mathrm{~mL}$ of potassium phosphate buffer ( $\mathrm{pH} 7.4)$ and packaged in a dialysis tube (MWCO: 3000 ). The sealed dialysis tube was placed in potassium phosphate buffer ( $\mathrm{pH} 7.4$ ) with or without $10 \mathrm{mM} \mathrm{GSH}$. The release experiment was performed at $37^{\circ} \mathrm{C}$ in a water bath at a rotating speed of $50 \mathrm{r} / \mathrm{min}$. At appropriate time intervals, $0.5 \mathrm{~mL}$ of the release media was withdrawn. Then, $0.5 \mathrm{~mL}$ of the fresh release medium was added back to the system to maintain the total volume. The cumulative release was calculated based on the test results.

Determination method. Potassium permanganate solution, $\mathrm{NaOH}$ solution, and deionized water were added sequentially to the sample. After incubation for $48 \mathrm{~h}$, the fluorescence signal of the final reaction mixture was monitored (RF-5301PC, SHIMADZU, Kyoto, Japan). The excitation wavelength was $286 \mathrm{~nm}$, and the emission wavelength was $397 \mathrm{~nm}$. 


\subsection{Cell Uptake Assay}

FITC-labelled HA (HA-FITC) was prepared for the cell uptake assay. HA (0.1 g) was dissolved in $8 \mathrm{~mL}$ of MES solution $(0.1 \mathrm{M})$. The $\mathrm{pH}$ was adjusted with $1 \mathrm{M} \mathrm{HCl}$ to $4.7, \mathrm{EDC}(0.24 \mathrm{~g})$ and NHS $(0.12 \mathrm{~g})$ were dissolved in the solution, and the solution was mixed under magnetic stirring for $15 \mathrm{~min}$. Cystamine dihydrochloride $(0.56 \mathrm{~g})$ was added, and the $\mathrm{pH}$ of the solution was adjusted to 5.5. After allowing the conjugation reaction to proceed for $3 \mathrm{~h}$, the reaction mixture was purified by successive dialysis (MWCO: 3000) against deionized water for $12 \mathrm{~h}$. The dialysis treatment was repeated four times. Finally, HA-cystamine was isolated after freeze-drying. Two millilitres of FITC in DMSO $(6.5 \mathrm{mg} / \mathrm{mL}$ ) was added to a sodium bicarbonate solution ( $\mathrm{pH} 9.3)$ of HA-cystamine $(30 \mathrm{mg} / 3 \mathrm{~mL}$ ), and the mixture was stirred for $2 \mathrm{~h}$ at room temperature. The reaction mixture was dialyzed against deionized water three times ( $3 \mathrm{~h}$ each time). Finally, the mixture was precipitated into anhydrous ethanol and washed twice with anhydrous ethanol. HA-FITC was obtained after the precipitate was dried at $40{ }^{\circ} \mathrm{C}$.

A549 cells (cultured in RPMI1640 supplemented with 10\% FBS, $1 \%$ penicillin, and 1\% streptomycin) and NIH/3T3 cells (cultured in DMEM supplemented with $10 \%$ FBS, $1 \%$ penicillin, and $1 \%$ streptomycin) were seeded in 12-well plates $\left(2 \times 10^{6} /\right.$ well $)$ and incubated for $24 \mathrm{~h}$ at $37^{\circ} \mathrm{C}$. Then, the culture medium was replaced with $1 \mathrm{~mL}$ of serum-free culture medium containing HA-FITC (the concentration of FITC was $2.5 \mu \mathrm{g} / \mathrm{mL}$ ) and incubated for $4 \mathrm{~h}$ at $37^{\circ} \mathrm{C}$. To test whether HA-FITC uptake was mediated by the CD44 receptor, $2.5 \mathrm{mg} / \mathrm{mL}$ free HA was added to one group of A549 cells and incubated for $2 \mathrm{~h}$ before the addition of HA-FITC.

After incubation with HA-FITC for $4 \mathrm{~h}$, the cells were washed three times with PBS ( $\mathrm{pH}$ 7.4) and then trypsinized. The cells were blown by pipet to form a cell suspension in complete culture medium and then centrifuged. Finally, the cells were suspended in $0.35 \mathrm{~mL}$ of PBS, and the fluorescence intensity of the cells was monitored by flow cytometry (BECKMAN FC500, Brea, CA, USA).

\subsection{Cell Viability Assays}

The cytotoxicity of HA-DOP-Cu-MP and 6-MP against A549 cells was evaluated using the MTT assay. Different concentrations of HA-SS-MP and 6-MP solutions were prepared. The cells were seeded in 96-well plates at a density of 4000 cells per well. After incubation for $24 \mathrm{~h}$, serum-free RPMI1640 culture medium containing different concentrations of HA-DOP-Cu-MP or 6-MP $(0.1,1,10$, and $100 \mu \mathrm{g} / \mathrm{mL}$ ) was added to displace the old cell culture medium. After incubation for $48 \mathrm{~h}, 100 \mu \mathrm{L}$ of RPMI1640 culture medium containing MTT was added to the cell culture medium and incubated for another $4 \mathrm{~h}$. Then, the RPMI1640 culture medium was removed, and $150 \mu \mathrm{L}$ of DMSO was added. Finally, the optical absorbance of the solution in each well was measured at $490 \mathrm{~nm}$ (iMark ${ }^{\mathrm{TM}}$ Microplate, Bio-Rad, Hercules, CA, USA), and the cell viability was calculated based on the absorbance.

\section{Results and Discussion}

\subsection{Synthetic Method}

\subsubsection{Study of the Coordination Abilities of $\mathrm{Cu}^{2+}, \mathrm{Zn}^{2+}, \mathrm{Fe}^{2+}$, and $\mathrm{Ca}^{2+}$ with 6-MP}

Most metal ions, especially transition metal ions, can be used as central atoms in complexes. The coordination abilities of 6-MP with $\mathrm{Cu}^{2+}, \mathrm{Zn}^{2+}, \mathrm{Fe}^{2+}$, and $\mathrm{Ca}^{2+}$ in aqueous solution were investigated and judged by whether a precipitate formed in aqueous solution. $\mathrm{Cu}^{2+}$ coordinated with 6-MP resulted in the formation of a brown precipitate in aqueous solution. In contrast, no precipitate was observed for $\mathrm{Zn}^{2+}, \mathrm{Fe}^{2+}$, and $\mathrm{Ca}^{2+}$. These experimental results implied that, among the metal ions tested, $\mathrm{Cu}^{2+}$ had the strongest coordination ability with 6-MP; therefore, $\mathrm{Cu}^{2+}$ was chosen as the central atom. The radius of the central atom strongly influences the stability of the resulting complex. The ionic radius of $\mathrm{Cu}^{2+}$ is the smallest among the metals tested (Figure 3), and as a result, the complex formed by $\mathrm{Cu}^{2+}$ is the most stable in aqueous solution. 


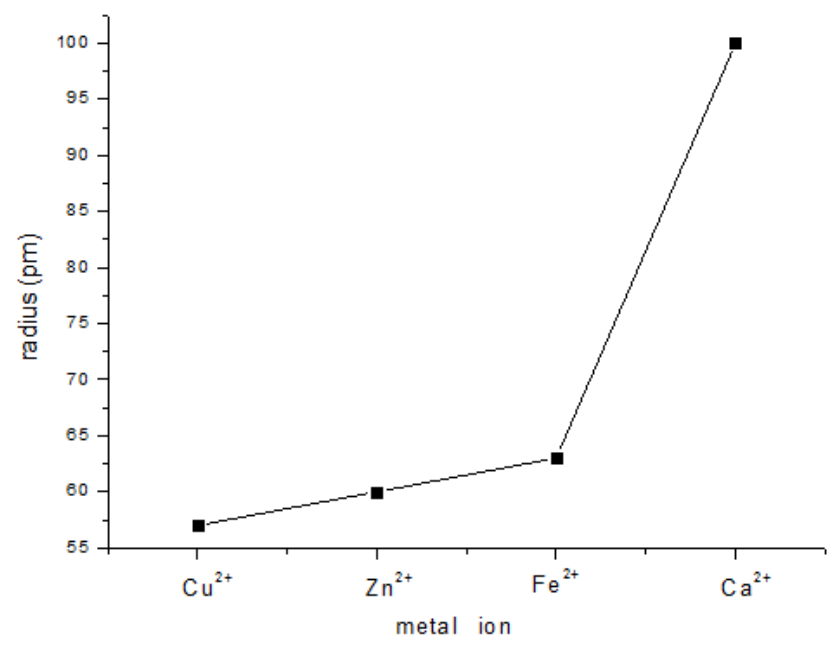

Figure 3. Plot showing the metal ion radii of $\mathrm{Cu}^{2+}, \mathrm{Zn}^{2+}, \mathrm{Fe}^{2+}$, and $\mathrm{Ca}^{2+}$.

\subsubsection{Study of the Stability of HA Derivatives Coordinated with $\mathrm{Cu}^{2+}$ and 6-MP}

Generally, ligand atoms are electronegative non-metal elements, and ligand groups are composed of elements such as $\mathrm{F}, \mathrm{Cl}, \mathrm{N}, \mathrm{O}$, and $\mathrm{S}$. HA contains carboxyl groups, which can form complexes with certain metal ions under specific conditions. In this paper, HA was modified by hexanediamine or dopamine, and the stability of modified or unmodified HA coordinated with copper ions and 6-MP was studied. Initially, the solutions were clear and transparent, indicating that HA, HA-HDA, and HA-DOP formed complexes with $\mathrm{Cu}$ ions and 6-MP. After $12 \mathrm{~h}, \mathrm{HA}-\mathrm{Cu}-\mathrm{MP}$ and HA-HDA-Cu-MP formed precipitates, indicating that the complexes formed via carboxyl and amino groups were unstable. In contrast, no precipitation was observed in the aqueous solution of HA-DOP-Cu-MP, indicating that the coordination ability of dopamine-modified HA is relatively strong. The HA-DOP-Cu-MP complexes dissolved and dispersed in aqueous solution in a stable manner. The simplest complex is formed by a monodentate ligand reacting with a central ion. The chelate is a cyclic structure complex, which is formed by a polydentate ligand and a central ion. Because of the ring structure, a chelate is more stable than a simple complex [41]. Amino groups and carboxyl groups form simple complexes with copper ions. The two ionized phenolic hydroxyl groups of the dopamine form bidentate complexes with copper ions, which were more stable than the simple complexes. Therefore, dopamine was selected to modify HA and enhance its coordination ability.

\subsection{Drug Loading, Entrapment Efficiency, and Solubilization Properties of HA-DOP-Cu-MP}

The drug loading of HA-DOP-Cu-MP was $49.5 \mathrm{mg} / \mathrm{g}$, and the encapsulation efficiency was $70.18 \%$. The solubility of 6-MP was $336 \mu \mathrm{g} / \mathrm{mL}$ in aqueous solution. The solubility of the MP in HA-DOP-Cu-MP exceeded $3812 \mu \mathrm{g} / \mathrm{mL}$ in aqueous solution. Compared with the solubility of free 6-MP, that of HA-DOP-Cu-MP was more than 10 times higher. Thus, the coordination polymer greatly improved the solubility of 6-MP. Therefore, this drug delivery system represents a new method for preparing 6-MP injections.

\subsection{Characterization of $H A-D O P-C u-M P$}

\subsubsection{Particle size of HA-DOP-Cu-MP}

The HA-DOP-Cu-MP coordination polymer consists of hydrophilic HA and hydrophobic 6-MP. In aqueous solution, HA forms a hydrophilic shell and 6-MP forms a hydrophobic core. The particle size of HA-DOP-Cu was $319.7 \mathrm{~nm}$ and the particle size of HA-DOP-Cu-MP was $173.5 \mathrm{~nm}$ (Table 1). The complexes formed by HA-DOP-Cu and 6-MP were further compressed by the hydrophobic interactions of 6-MP, and as a result, the particle size decreased compared with HA-DOP-Cu. In many 
solid tumours, the vascular endothelial cell tissue will form pores with diameters of $200 \mathrm{~nm}$ to $1.2 \mu \mathrm{m}$ because of its rapid growth [42]. In addition, the lymphatic drainage is impaired. Therefore, HA-DOP-Cu-MP nanoparticles can flow through the tumour vessels in the blood circulation and accumulate in the loose tumour tissues because of the enhanced permeability and retention (EPR) effect [43].

Table 1. Particle sizes of dopamine-modified hyaluronic acid (HA-DOP)-Cu-MP $(n=3)$.

\begin{tabular}{ccc}
\hline Sample & Particle Size (nm) & Polydispersity Index (PDI) \\
\hline HA-DOP-Cu & $319.7 \pm 25.0$ & $0.529 \pm 0.10$ \\
HA-DOP-Cu-MP & $173.5 \pm 5.4$ & $0.363 \pm 0.01$ \\
\hline
\end{tabular}

\subsubsection{Characterization of the ${ }^{1} \mathrm{H}-\mathrm{NMR}$ Spectrum}

The difference between the ${ }^{1} \mathrm{H}-\mathrm{NMR}$ spectra of the complex and the organic compounds is caused by the metal ions in the complex. The impact of different metal ions on the ${ }^{1} \mathrm{H}-\mathrm{NMR}$ spectra of complexes is different. Depending on whether a net magnetic moment is present, metal ions are classified into paramagnetic metal ions and anti-magnetic metal ions. The impact of diamagnetic metal ions on the ${ }^{1} \mathrm{H}-\mathrm{NMR}$ spectra of complexes is not significant, while paramagnetic metal ions strongly affect the ${ }^{1} \mathrm{H}-\mathrm{NMR}$ spectra of complexes owing to the existence of a magnetic field. As a result, the ligand of a complex is not detected. These changes can be used to determine whether the metal ion is coordinated with the ligand.

The characteristic peaks at 6.79-7.12 ppm were assigned to the protons of the dopamine moiety (Figure 4A) [44,45]. After the phenolic hydroxyl groups on the dopamine formed a complex with the metal ions, the protons on the ligands were replaced by metal ions, forming lone pair electrons. $\mathrm{Cu}^{2+}$, which contains unpaired electrons, is a paramagnetic metal ion [46]. Under the influence of $\mathrm{Cu}^{2+}$, the ${ }^{1} \mathrm{H}-\mathrm{NMR}$ peaks of the dopamine groups disappeared (Figure 4B) [47]. Therefore, $\mathrm{Cu}^{2+}, 6-\mathrm{MP}$, and HA-DOP formed complexes.

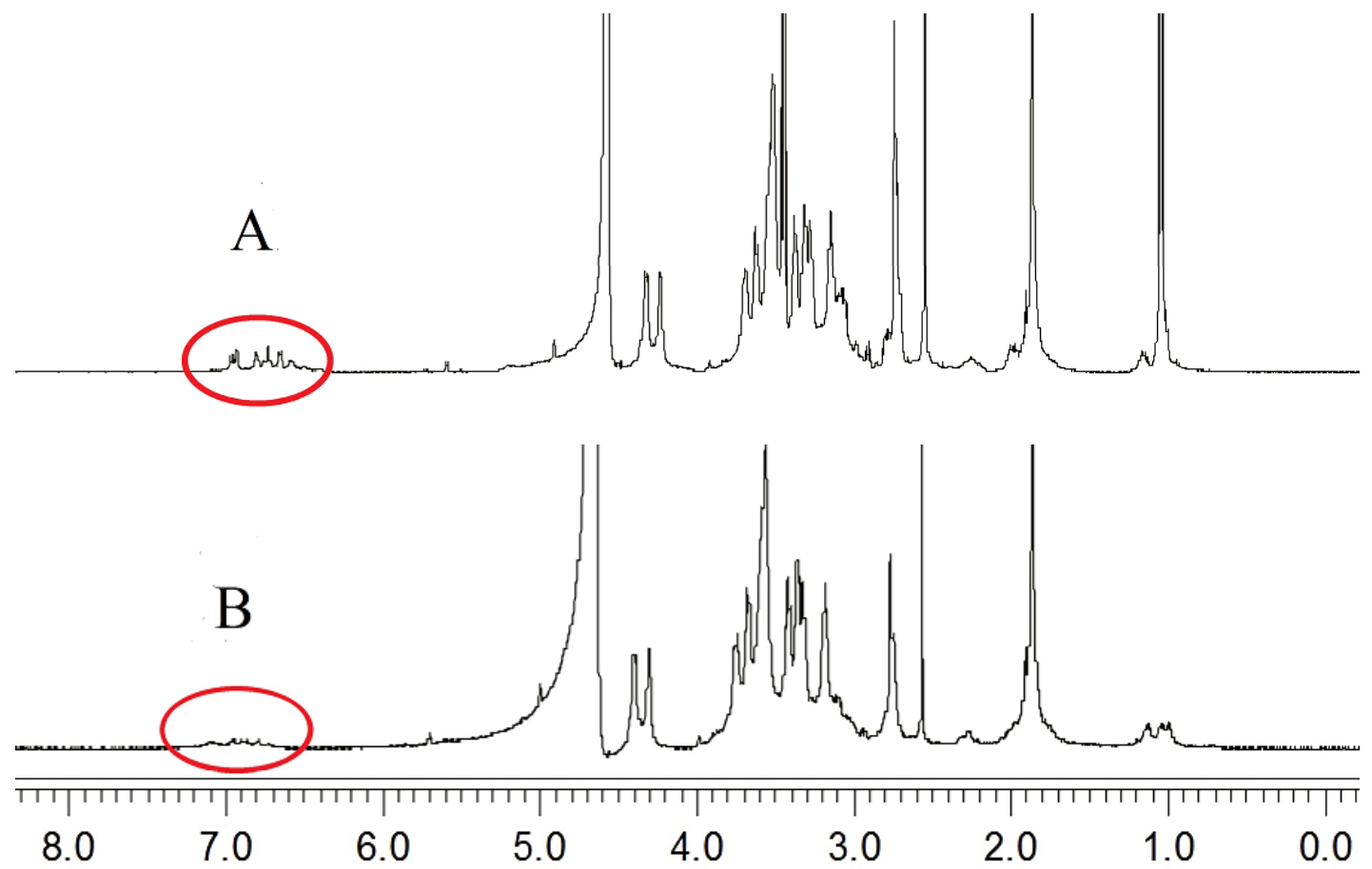

Figure 4. ${ }^{1} \mathrm{H}-\mathrm{NMR}$ spectra of (A) HA-DOP and (B) HA-DOP-Cu-MP. 


\subsubsection{FT-IR Spectroscopy Measurement}

The FT-IR spectra collected over the spectral range of $400-4000 \mathrm{~cm}^{-1}$ for 6-MP, HA-DOP, and HA-DOP-Cu-MP are presented in Figure 5.

The band at $3425.95 \mathrm{~cm}^{-1}$ is assigned to the O-H of HA. The band at $2924.23 \mathrm{~cm}^{-1}$ corresponds to $\mathrm{C}-\mathrm{H}_{2}$ stretching, whereas that at $1638.87 \mathrm{~cm}^{-1}$ represents $\mathrm{C}=\mathrm{O}$ stretching. The band at $1568.94 \mathrm{~cm}^{-1}$ is ascribed to N-H stretching, and the band at $1409.99 \mathrm{~cm}^{-1}$ corresponds to the $\mathrm{C}-\mathrm{O}$ stretching of $\mathrm{COOH}$. The band at $1296.85 \mathrm{~cm}^{-1}$ indicates the $\mathrm{O}-\mathrm{H}$ stretching of $\mathrm{COOH}$, whereas those at $1079.79 \mathrm{~cm}^{-1}$ and $1041.92 \mathrm{~cm}^{-1}$ reflect the O-H stretching of $\mathrm{C}-\mathrm{OH}$ (Figure 5).

The band at $871.6 \mathrm{~cm}^{-1}$ is attributed to N-H stretching in 6-MP [48]. The electron density of the purine ring increased after 6-MP coordinated with $\mathrm{Cu}^{2+}$, forming a more stable structure. As a result, the absorption band of the N-H of the purine ring of the HA-DOP-Cu-MP complex was red-shifted to $878.7 \mathrm{~cm}^{-1}$. Because of the electron and steric hindrance effects of the copper ions, most of the absorption bands of 6-MP were displaced or disappeared.

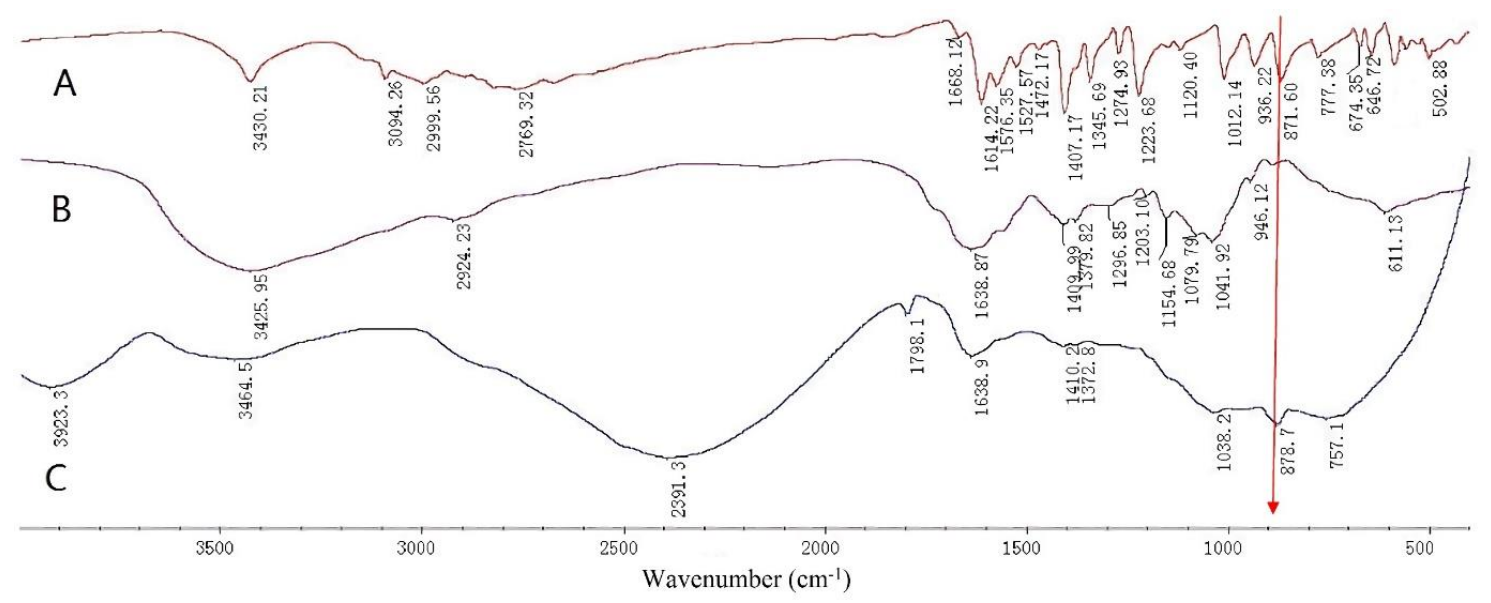

Figure 5. Fourier transform infrared (FT-IR) spectra of (A) 6-mercaptopurine (6-MP), (B) HA-DOP, and (C) HA-DOP-Cu-MP.

\subsubsection{XRD Spectra}

The diffraction pattern for pure 6-MP contained distinct peaks at $2 \theta=11.7{ }^{\circ} \mathrm{C}, 14.5^{\circ} \mathrm{C}, 20.5^{\circ} \mathrm{C}$, $23.5^{\circ} \mathrm{C}, 25.2^{\circ} \mathrm{C}, 27.5^{\circ} \mathrm{C}, 29.4^{\circ} \mathrm{C}$, and $30.4^{\circ} \mathrm{C}$. The XRD crystal diffraction pattern (Figure $6 \mathrm{~A}$ ) shows that 6-MP exists as crystals. No characteristic diffraction peaks were found in HA-DOP-Cu-MP (Figure 6B). Indeed, when 6-MP coordinated with HA-DOP and $\mathrm{Cu}^{2+}$, it became highly dispersed in the coordination polymer and formed an amorphous structure. Crystalline compounds typically have poor solubility and dissolve slowly, affecting drug absorption and bioavailability. In the HA-DOP-Cu-MP complex, 6-MP exists in an amorphous form, which increases the drug solubility and dissolution rate and is favourable for the dissolution and absorption of the drug. 


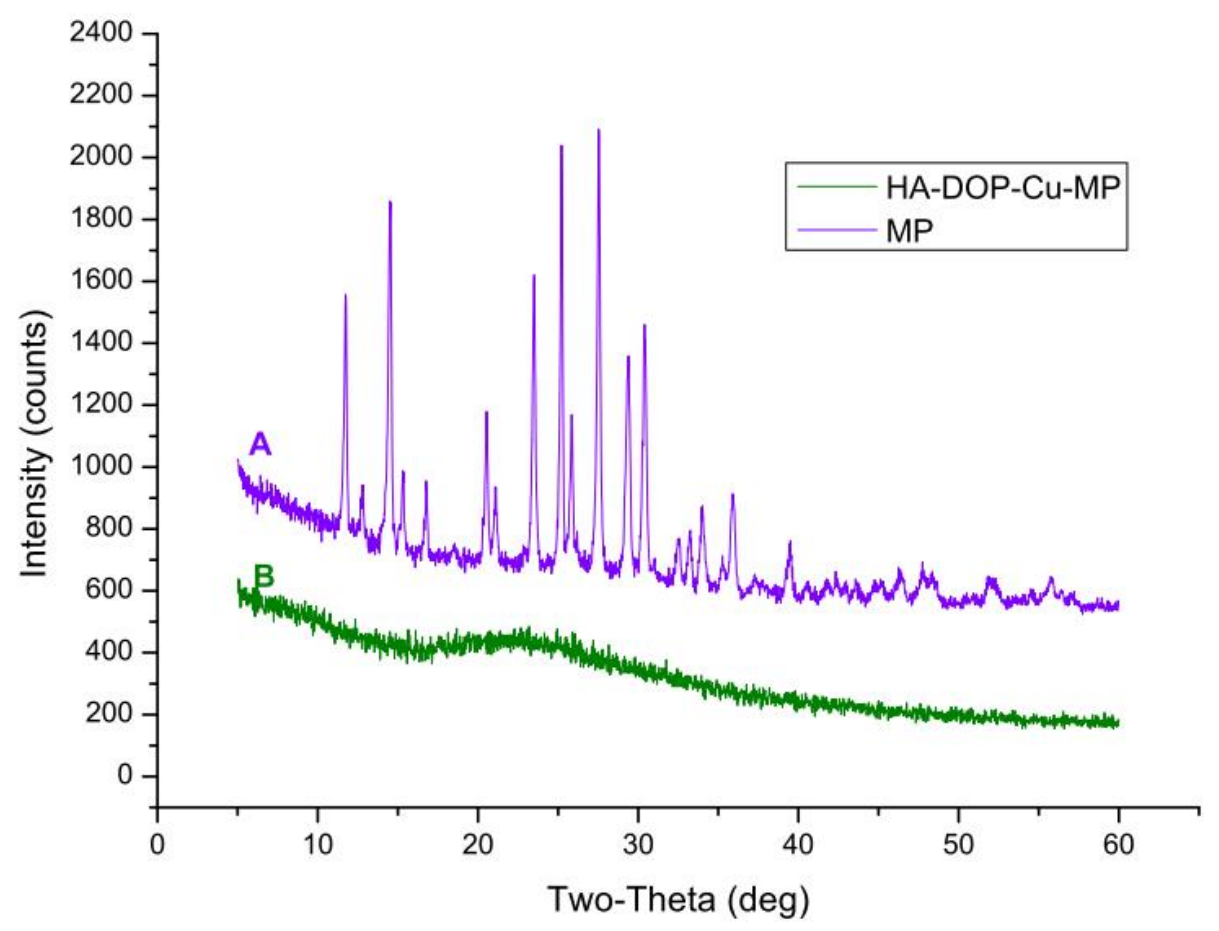

Figure 6. X-ray diffraction (XRD) patterns for (A) 6-MP and (B) HA-DOP-Cu-MP.

\subsection{Drug Release Experiment}

Various models have been developed in the field of pharmacy to fit the release behaviour of drugs. The zero-order release rate is constant and unchanging over a period of time, and thus is the ideal release model for controlled release preparations. Drug delivery devices with a zero-order release include osmotic pump and transdermal formulations. First-order release is one of the most common drug release models and consists of the exponential decay of the drug release rate over time. The typical dosage form that follows a first-order release is a water-soluble mesoporous matrix. The Higuchi model is used to fit the skeletal diffusion drug release curve. The Peppas model is an equation that describes dissolution and diffusion and is suitable for polymer drug delivery systems [49].

The data from the in vitro release studies were fitted by various release models [50]. When the release medium contained no GSH, the release profile showed a good fit to the Peppas release model $(\mathrm{R}=0.9808)$ compared with the other models (Table 2$)$, indicating that the HA-DOP-Cu-MP coordination polymer had a good sustained release effect. When the release medium contained $10 \mathrm{mM}$ GSH, the release profile showed a good fit to the first-order release model, indicating that the drug release rate of HA-DOP-Cu-MP was fast, that the drug concentration in the carrier decreased rapidly, and that the release rate exponentially attenuated with time. The in vitro drug release curve is shown in Figure 7.

The influence of GSH on the release behaviour of HA-DOP-Cu-MP was investigated in in vitro release experiments. When $10 \mathrm{mM}$ GSH was added to the release medium, the accumulative release amount of 6-MP exceeded $94 \%$ in $2 \mathrm{~h}$. The concentration of GSH in cancer cells exceeded $10 \mathrm{mM}$, suggesting that HA-DOP-Cu-MP coordination polymer releases 6-MP rapidly to kill cancer cells.

In contrast, in the absence of the GSH, the cumulative release amount was only approximately $15 \%$ in $24 \mathrm{~h}$, indicating that HA-DOP-Cu-MP is stable in the systemic circulation. This release characteristic reduces the toxic side effects of drugs to healthy cells. 


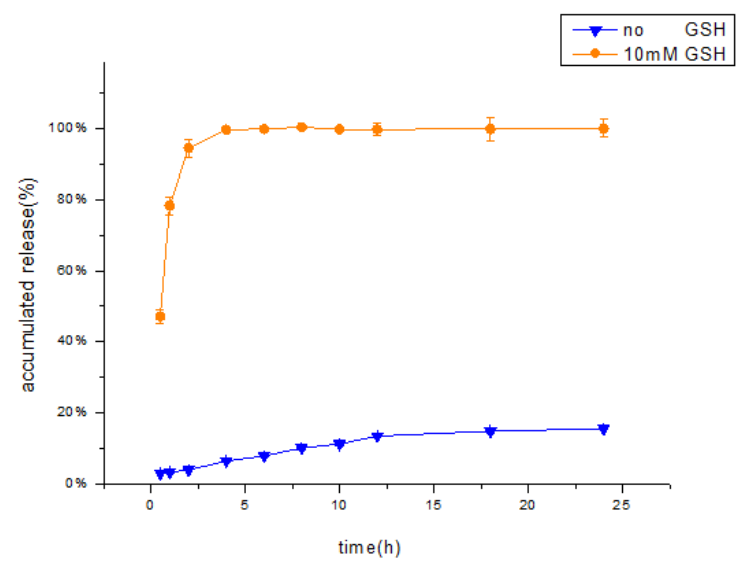

Figure 7. In Vitro cumulative percentage release of MP from HA-DOP-Cu-MP nanoparticles in $\mathrm{pH} 7.4$ phosphate buffer solution ( $\rightarrow$ no GSH, $\rightarrow 10 \mathrm{mM} \mathrm{GSH}$ ). The dialysis bag method was used to conduct the release study at $37^{\circ} \mathrm{C}$ in a shaker bath $(50 \mathrm{rpm})$.

Table 2. Correlation coefficient obtained by fitting the data for the release of MP from HA-DOP-Cu-MP into a buffered solution at $\mathrm{pH} 7.4$ (with or without $10 \mathrm{mM}$ glutathione (GSH)).

\begin{tabular}{cccc}
\hline Models & Formula & R (no GSH) & R (10 mM GSH) \\
\hline Zero-order & $\mathrm{M}_{\mathrm{t}} / \mathrm{M}_{\infty}=\mathrm{k} \cdot \mathrm{t}+\mathrm{k}_{0}$ & 0.8968 & 0.2763 \\
First-order & $\ln \left(1-\mathrm{M}_{\mathrm{t}} / \mathrm{M}_{\infty}\right)=\mathrm{k} \cdot \mathrm{t}+\mathrm{k}_{0}$ & 0.9647 & 0.9926 \\
Higuchi & $\mathrm{M}_{\mathrm{t}} / \mathrm{M}_{\infty}=\mathrm{k} \cdot \mathrm{t}_{1 / 2}+\mathrm{k}_{0}$ & 0.9704 & 0.4506 \\
Peppas & $\mathrm{M}_{\mathrm{t}} / \mathrm{M}_{\infty}=\mathrm{k} \cdot \mathrm{t}^{\mathrm{n}}$ & 0.9808 & 0.8446 \\
\hline
\end{tabular}

\subsection{Cell Uptake Assay}

The cellular uptake efficiency of HA-FITC was evaluated by flow cytometry (Figure 8). A549 cells overexpress the CD44 receptor (CD44+) [51]. The fluorescence signal was decreased obviously when A549 cells were pre-treated with free HA (A549 + HA) (Figure 9), confirming that HA competitively inhibited the uptake of HA-FITC by A549 cells. This result demonstrated that HA was internalized by CD44 + A549 cells via receptor mediated endocytosis, indicating that HA could specifically target the $\mathrm{CD} 44$ receptor.

$\mathrm{NIH} / 3 \mathrm{~T} 3$ cells (mouse embryonic fibroblasts cells) were used as CD44-receptor-negative cell lines (CD44-) [52,53]. The fluorescence signal in A549 cells was more intense than that in NIH/3T3 cells $(* * p<0.01)$ (Figure 9), because HA-FITC could only enter the NIH/3T3 cells (CD44-) through nonspecific endocytosis. In contrast, HA-FITC could be rapidly internalized by A549 cells (CD44+) via receptor mediated endocytosis. The cell uptake experiments showed that HA was more readily internalized by cancer cells (A549) than by healthy cells (NIH/3T3). Therefore, this HA drug delivery carrier reduces the toxic side effects of drugs on healthy cells. 


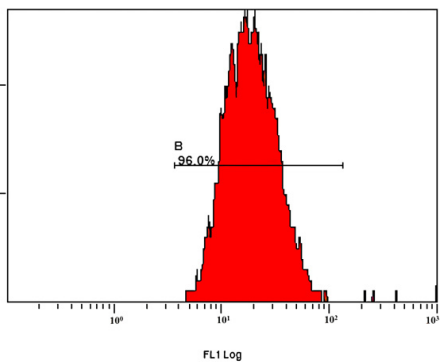

(A) A549

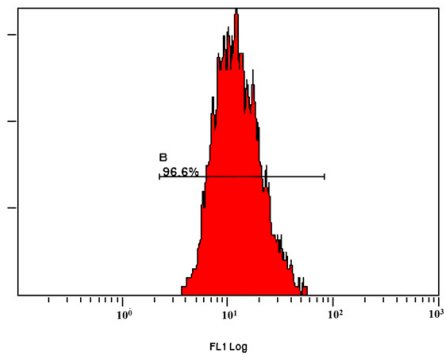

(B) $\mathrm{A} 549+\mathrm{HA}$

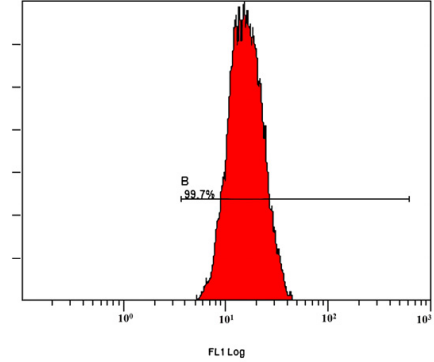

(C) $\mathrm{NIH} / 3 \mathrm{~T} 3$

Figure 8. Flow cytometry analysis of the specific endocytosis of fluorescein isothiocyanate isomer I (FITC)-labelled HA internalized by (A) A549 cells, (B) A549 cells pre-treated for $2 \mathrm{~h}$ with free HA $(2.5 \mathrm{mg} / \mathrm{mL})$, and (C) NIH-3T3 cells.

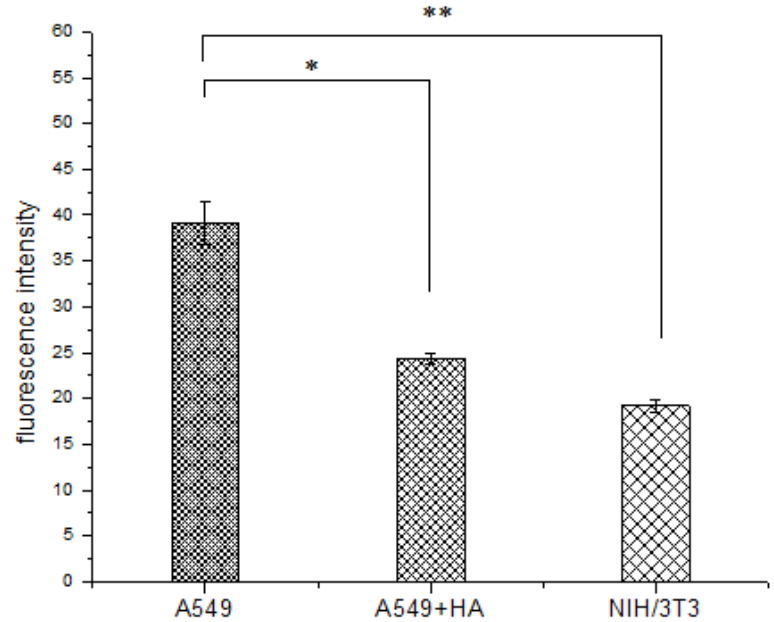

Figure 9. Fluorescence intensity of FITC-labelled HA in A549 cells, A549 cells pre-treated with free HA (A549 + HA), and NIH/3T3 cells. Data are shown as the mean \pm standard deviation (SD) $(n=3)$. Statistically significant differences are indicated by $*(p<0.05)$ and ${ }^{* *}(p<0.01)$.

\subsection{Cell Viability Assays}

The survival rate of human lung adenocarcinoma cells (A549) treated with HA-DOP-Cu-MP and 6-MP decreased as the drug concentration increased after $48 \mathrm{~h}$ of administration, and a significant dose-effect relationship was observed (Figure 10). A549 cells overexpress the CD44 receptor and P-gp protein [54]. In tumour cells, the P-gp protein pumps free drugs out of the cell and reduces their cytotoxicity. Nanoparticles are not readily recognized by the efflux pumps after entering cells, and thus they can escape capture by the P-gp protein [55]. In addition, HA nanoparticles are more rapidly absorbed by cells via CD44-mediated endocytosis, and as a result, the cytotoxicity of HA-DOP-Cu-MP to A549 is higher than that of free 6-MP. HA-DOP-Cu-MP is effectively internalized by cancer cells and exhibits good anticancer activity. 


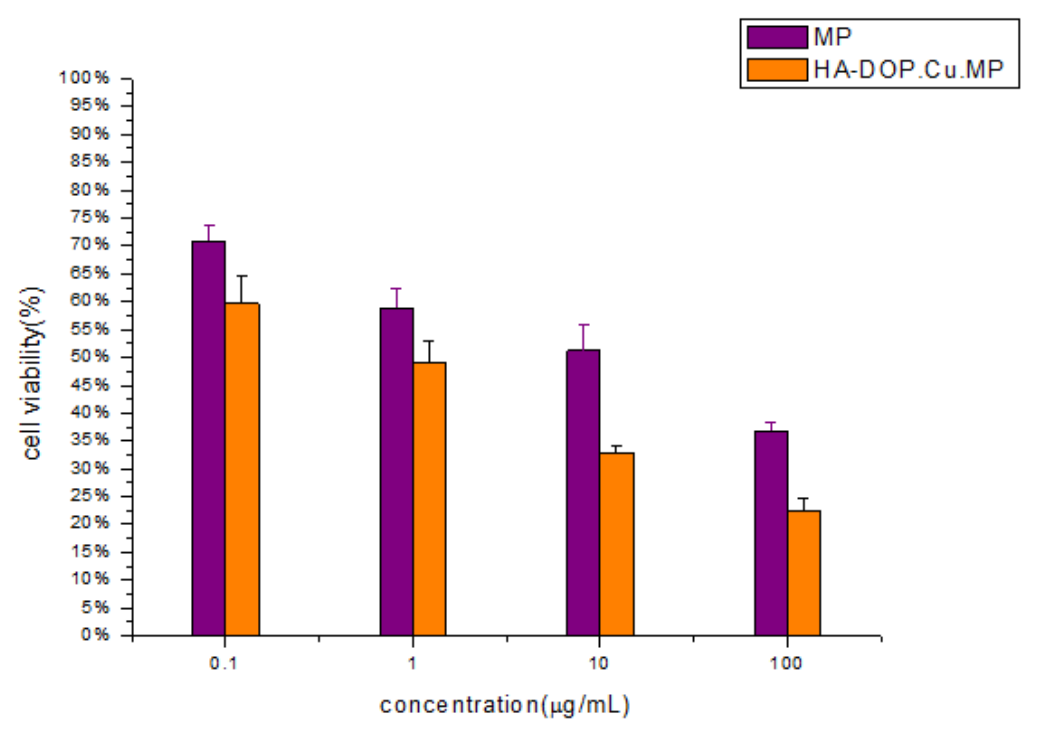

Figure 10. In vitro cytotoxicity of HA-DOP-Cu-MP nanoparticles and 6-MP at various concentrations against A549 cells. Data are shown as the mean \pm SD $(n=3)$. The A549 cells were seeded at a density of $4 \times 10^{3}$ cells/well in 96-well microtitre plates. The cell viability of the cells was measured after $48 \mathrm{~h}$ by 3-(4,5-dimethylthiazol-2-yl)-2,5-diphenyltetrazolium bromide (MTT) assay. Error bars are based on the SD determined via triplicate experiments $(n=3)$.

\section{Conclusions}

In this study, redox-responsive HA-DOP-Cu-MP coordination polymers were synthesized by a coordination reaction. The synthesis method was simple, and the solubility of 6-MP was improved. The release rate was slow in the release medium without GSH; this release characteristic is favourable for the stability of the drug in the systemic circulation and for reducing the side effects on healthy cells. When the release medium contained $10 \mathrm{mM} \mathrm{GSH}$, the accumulated release amount was approximately $94 \%$ in $2 \mathrm{~h}$, indicating that the coordination polymers can quickly release 6-MP in tumour cells containing GSH. After entering the blood circulation, HA-DOP-Cu-MP accumulates in the loose tumor tissue through the EPR effect, and then HA-DOP-Cu-MP can be internalized by tumour cells through CD44-mediated endocytosis. The killing effect of HA-DOP-Cu-MP against tumour cells was better than that of free 6-MP. Indeed, HA-DOP-Cu-MP coordination polymers effectively kill cancer cells and reduce systemic toxicity. Therefore, these targeting coordination polymers have great potential applications in drug delivery for cancer therapy.

Currently, redox-responsive drug delivery systems are typically based on disulfide bonds, which are broken by the reduction of GSH to release drugs. Less research has been focused on coordination polymer drug delivery systems, with most studies addressing $\mathrm{pH}$ responsiveness. This work revealed that thiol compounds can be linked to polymers by coordination reactions. The HA-DOP-Cu-MP coordination polymer releases free drugs in a release medium containing GSH and has an excellent redox-responsive targeting. This hyaluronic acid drug delivery system can be used to prepare 6-MP injections. Thus, this study provides a new strategy for the development of redox-responsive drug delivery systems.

Author Contributions: B.T. designed and performed the experiments, analyzed the data, and wrote the paper; Z.Y. designed the experiments and revised the paper. All authors have read and agreed to the published version of the manuscript.

Funding: This research was financially supported by the Natural Science Foundation of China (No. 81373338).

Conflicts of Interest: The authors declare no conflict of interest. 


\section{References}

1. Alemrayat, B.; Elhissi, A.; Younes, H.M. Preparation and characterization of letrozole-loaded poly (d, 1-lactide) nanoparticles for drug delivery in breast cancer therapy. Pharm. Dev. Technol. 2019, 24, 235-242. [CrossRef] [PubMed]

2. Alemrayat, B.; Elrayess, M.A.; Alany, R.G.; Elhissi, A.; Younes, H.M. Preparation and optimization of monodisperse polymeric microparticles using modified vibrating orifice aerosol generator for controlled delivery of letrozole in breast cancer therapy. Drug Dev. Ind. Pharm 2018, 44, 1953-1965. [CrossRef] [PubMed]

3. Grigoletto, A.; Maso, K.; Mero, A.; Rosato, A.; Schiavon, O.; Pasut, G. Drug and protein delivery by polymer conjugation. J. Drug Deliv. Sci. Technol. 2016, 32, 132-141. [CrossRef]

4. Mora-Huertas, C.E.; Fessi, H.; Elaissari, A. Polymer-based nanocapsules for drug delivery. Int. J. Pharm. 2010, 385, 113-142. [CrossRef] [PubMed]

5. Vauthier, C.; Dubernet, C.; Chauvierre, C.; Brigger, I.; Couvreur, P. Drug delivery to resistant tumors: The potential of poly (alkyl cyanoacrylate) nanoparticles. J. Control. Release 2003, 93, 151-160. [CrossRef] [PubMed]

6. Tuba, F.; Oláh, L.; Nagy, P. Characterization of reactively compatibilized poly (d, l-lactide)/poly ( $\varepsilon$-caprolactone) biodegradable blends by essential work of fracture method. Eng. Fract. Mech. 2011, 78, 3123-3133. [CrossRef]

7. Liu, M.; Du, H.; Zhang, W.; Zhai, G. Internal stimuli-responsive nanocarriers for drug delivery: Design strategies and applications. Mater. Sci. Eng. C 2017, 71, 1267-1280. [CrossRef]

8. Karimi, M.; Ghasemi, A.; Zangabad, P.S.; Rahighi, R.; Basri, S.M.M.; Mirshekari, H.; Amiri, M.; Pishabad, Z.S.; Aslani, A.; Bozorgomid, M. Smart micro/nanoparticles in stimulus-responsive drug/gene delivery systems. Chem. Soc. Rev. 2016, 45, 1457-1501. [CrossRef]

9. Sonawane, S.J.; Kalhapure, R.S.; Govender, T. Hydrazone linkages in $\mathrm{pH}$ responsive drug delivery systems. Eur. J. Pharm. Sci. 2017, 99, 45-65. [CrossRef]

10. Kanamala, M.; Wilson, W.R.; Yang, M.; Palmer, B.D.; Wu, Z. Mechanisms and biomaterials in pH-responsive tumour targeted drug delivery: A review. Biomaterials 2016, 85, 152-167. [CrossRef]

11. Medina, S.H.; Chevliakov, M.V.; Tiruchinapally, G.; Durmaz, Y.Y.; Kuruvilla, S.P.; ElSayed, M.E. Enzyme-activated nanoconjugates for tunable release of doxorubicin in hepatic cancer cells. Biomaterials 2013, 34, 4655-4666. [CrossRef] [PubMed]

12. Shin, J.M.; Hwang, S.R.; Heo, R.; Saravanakumar, G.; Park, J.H. Amphiphilic hyaluronic acid derivative with the bioreducible bond: Synthesis and its implication for intracellular drug delivery. Polym. Degrad. Stab. 2014, 109, 398-404. [CrossRef]

13. Crabb, E.; Moore, E.A. Metals and Life; RSC Publishing: Cambridge, UK, 2009.

14. Ndagi, U.; Mhlongo, N.; Soliman, M.E. Metal complexes in cancer therapy-an update from drug design perspective. Drug Des. Dev. Ther. 2017, 11, 599. [CrossRef] [PubMed]

15. Johnson, T.J.; Hedge, D.D. Esomeprazole: A clinical review. Am. J. Health Syst. Pharm. 2002, 59, $1333-1339$. [CrossRef]

16. Lee, J.-E.; In, I.; Lee, H.; Lee, K.D.; Jeong, J.H.; Park, S.Y. Target delivery and cell imaging using hyaluronic acid-functionalized graphene quantum dots. Mol. Pharm. 2013, 10, 3736-3744.

17. Kurzwernhart, A.; Kandioller, W.; Bartel, C.; Bächler, S.; Trondl, R.; Mühlgassner, G.; Jakupec, M.A.; Arion, V.B.; Marko, D.; Keppler, B.K. Targeting the DNA-topoisomerase complex in a double-strike approach with a topoisomerase inhibiting moiety and covalent DNA binder. Chem. Commun. 2012, 48, 4839-4841. [CrossRef]

18. Hall, M.D.; Failes, T.W.; Yamamoto, N.; Hambley, T.W. Bioreductive activation and drug chaperoning in cobalt pharmaceuticals. Dalton Trans. 2007, 36, 3983-3990. [CrossRef]

19. Salierno, M.; Marceca, E.; Peterka, D.S.; Yuste, R.; Etchenique, R. A fast ruthenium polypyridine cage complex photoreleases glutamate with visible or IR light in one and two photon regimes. J. Inorg. Biochem. 2010, 104, 418-422. [CrossRef]

20. Yan, Y.; Zhang, J.; Ren, L.; Tang, C. Metal-containing and related polymers for biomedical applications. Chem. Soc. Rev. 2016, 45, 5232-5263. [CrossRef]

21. Novio, F.; Simmchen, J.; Vázquez-Mera, N.; Amorín-Ferré, L.; Ruiz-Molina, D. Coordination polymer nanoparticles in medicine. Coord. Chem. Rev. 2013, 257, 2839-2847. [CrossRef] 
22. Sedó, J.; Saiz-Poseu, J.; Busqué, F.; Ruiz-Molina, D. Catechol-Based Biomimetic Functional Materials. Adv. Mater. 2013, 25, 653-701. [CrossRef] [PubMed]

23. Thorner, M. Dopamine is an important neurotransmitter in the autonomic nervous system. Lancet 1975, 305, 662-665. [CrossRef]

24. Holten-Andersen, N.; Harrington, M.J.; Birkedal, H.; Lee, B.P.; Messersmith, P.B.; Lee, K.Y.C.; Waite, J.H. $\mathrm{pH}$-induced metal-ligand cross-links inspired by mussel yield self-healing polymer networks with near-covalent elastic moduli. Proc. Natl. Acad. Sci. USA 2011, 108, 2651-2655. [CrossRef] [PubMed]

25. Dosio, F.; Arpicco, S.; Stella, B.; Fattal, E. Hyaluronic acid for anticancer drug and nucleic acid delivery. Adv. Drug Delivery Rev. 2016, 97, 204-236. [CrossRef] [PubMed]

26. Huerta-Ángeles, G.; Knotková, K.; Knotek, P.; Židek, O.; Brandejsová, M.; Pokorný, M.; Vagnerová, H.; Roy, I.; Velebný, V. Aligned nanofibres made of poly (3-hydroxybutyrate) grafted to hyaluronan for potential healthcare applications. J. Mater. Sci. Mater. Med. 2018, 29, 32. [CrossRef]

27. Park, J.B.; Kwak, H.-J.; Lee, S.-H. Role of hyaluronan in glioma invasion. Cell. Adhes. Migr. 2008, 2, $202-207$. [CrossRef]

28. Baranova, N.S.; Nilebäck, E.; Haller, F.M.; Briggs, D.C.; Svedhem, S.; Day, A.J.; Richter, R.P. The inflammation-associated protein TSG-6 cross-links hyaluronan via hyaluronan-induced TSG-6 oligomers. J. Biol. Chem. 2011, 286, 25675-25686. [CrossRef]

29. Liu, L.-K.; Finzel, B.C. Fragment-based identification of an inducible binding site on cell surface receptor CD44 for the design of protein-carbohydrate interaction inhibitors. J. Med. Chem. 2014, 57, 2714-2725. [CrossRef]

30. Oh, E.J.; Park, K.; Kim, K.S.; Kim, J.; Yang, J.-A.; Kong, J.-H.; Lee, M.Y.; Hoffman, A.S.; Hahn, S.K. Target specific and long-acting delivery of protein, peptide, and nucleotide therapeutics using hyaluronic acid derivatives. J. Control. Release 2010, 141, 2-12. [CrossRef]

31. Lennard, L. The clinical pharmacology of 6-mercaptopurine. Eur. J. Clin. Pharmacol. 1992, 43, 329-339. [CrossRef]

32. Yang, Y.; Zhou, S.; Ouyang, R.; Yang, Y.; Tao, H.; Feng, K.; Zhang, X.; Xiong, F.; Guo, N.; Zong, T. Improvement in the Anticancer Activity of 6-Mercaptopurine via Combination with Bismuth (III). Chem. Pharm. Bull. 2016, 64, 1539-1545. [CrossRef] [PubMed]

33. Xu, L.-L.; Chen, J.-M.; Yan, Y.; Lu, T.-B. Improving the solubility of 6-Mercaptopurine via cocrystals and salts. Cryst. Growth Des. 2012, 12, 6004-6011. [CrossRef]

34. Zheng, H.; Rao, Y.; Yin, Y.; Xiong, X.; Xu, P.; Lu, B. Preparation, characterization, and in vitro drug release behavior of 6-mercaptopurine-carboxymethyl chitosan. Carbohydr. Polym. 2011, 83, 1952-1958. [CrossRef]

35. Guo, X.; Cheng, Y.; Zhao, X.; Luo, Y.; Chen, J.; Yuan, W.-E. Advances in redox-responsive drug delivery systems of tumor microenvironment. J. Nanobiotechnol. 2018, 16, 74. [CrossRef] [PubMed]

36. Kumari, S.; Badana, A.K.; Malla, R. Reactive oxygen species: A key constituent in cancer survival. Biomark. Insights 2018, 13, 1177271918755391. [CrossRef] [PubMed]

37. Traverso, N.; Ricciarelli, R.; Nitti, M.; Marengo, B.; Furfaro, A.L.; Pronzato, M.A.; Marinari, U.M.; Domenicotti, C. Role of glutathione in cancer progression and chemoresistance. Oxid. Med. Cell. Longev. 2013, 2013, 972913. [CrossRef]

38. Russo, A.; DeGraff, W.; Friedman, N.; Mitchell, J.B. Selective modulation of glutathione levels in human normal versus tumor cells and subsequent differential response to chemotherapy drugs. Cancer Res. 1986, 46, 2845-2848.

39. Golombek, S.K.; May, J.-N.; Theek, B.; Appold, L.; Drude, N.; Kiessling, F.; Lammers, T. Tumor targeting via EPR: Strategies to enhance patient responses. Adv. Drug Deliv. Rev. 2018, 130, 17-38. [CrossRef]

40. Torchilin, V. Tumor delivery of macromolecular drugs based on the EPR effect. Adv. Drug Deliv. Rev. 2011, 63, 131-135. [CrossRef]

41. McCleverty, J.A.; Meyer, T.J. Comprehensive Coordination Chemistry II; Elsevier Ltd.: Amsterdam, The Netherlands, 2004.

42. Hobbs, S.K.; Monsky, W.L.; Yuan, F.; Roberts, W.G.; Griffith, L.; Torchilin, V.P.; Jain, R.K. Regulation of transport pathways in tumor vessels: Role of tumor type and microenvironment. Proc. Natl. Acad. Sci. USA 1998, 95, 4607-4612. [CrossRef] 
43. Maeda, H.; Nakamura, H.; Fang, J. The EPR effect for macromolecular drug delivery to solid tumors: Improvement of tumor uptake, lowering of systemic toxicity, and distinct tumor imaging in vivo. Adv. Drug Deliv. Rev. 2013, 65, 71-79. [CrossRef] [PubMed]

44. Martínez, A.; Vageli, O.; Pfleiderer, W.; Flatmark, T. Proton NMR studies on the conformation of the pterin cofactor bound at the active site of recombinant human tyrosine hydroxylase. Pteridines 1998, 9, 44-52. [CrossRef]

45. Neto, A.I.; Cibrão, A.C.; Correia, C.R.; Carvalho, R.R.; Luz, G.M.; Ferrer, G.G.; Botelho, G.; Picart, C.; Alves, N.M.; Mano, J.F. Nanostructured polymeric coatings based on chitosan and dopamine-modified hyaluronic acid for biomedical applications. Small 2014, 10, 2459-2469. [CrossRef] [PubMed]

46. Yıldırım, İ.; Çelik, Y.; Karabulut, B. Characterizing the paramagnetic behavior of $\mathrm{Cu}^{2+}$ doped nickel (II) dipicolinato by using theoretical and experimental EPR and UV-vis studies. Physica. B Condens. Matter 2016, 483, 90-93.

47. Qiao, H.; Sun, M.; Su, Z.; Xie, Y.; Chen, M.; Zong, L.; Gao, Y.; Li, H.; Qi, J.; Zhao, Q. Kidney-specific drug delivery system for renal fibrosis based on coordination-driven assembly of catechol-derived chitosan. Biomaterials 2014, 35, 7157-7171. [CrossRef]

48. Bariyanga, J.; Luyt, A. Synthesis, Fourier transform infrared, nuclear magnetic resonance and thermal analysis of sodium and platinum complexes of 6-mercaptopurine. J. Mol. Struct. 2001, 559, 49-54. [CrossRef]

49. Dash, S.; Murthy, P.N.; Nath, L.; Chowdhury, P. Kinetic modeling on drug release from controlled drug delivery systems. Acta. Pol. Pharm. 2010, 67, 217-223.

50. Zhang, Y.; Huo, M.; Zhou, J.; Zou, A.; Li, W.; Yao, C.; Xie, S. DDSolver: An add-in program for modeling and comparison of drug dissolution profiles. AAPS J. 2010, 12, 263-271. [CrossRef]

51. Yang, C.; Wang, X.; Yao, X.; Zhang, Y.; Wu, W.; Jiang, X. Hyaluronic acid nanogels with enzyme-sensitive cross-linking group for drug delivery. J. Control. Release 2015, 205, 206-217. [CrossRef]

52. Arabi, L.; Badiee, A.; Mosaffa, F.; Jaafari, M.R. Targeting CD44 expressing cancer cells with anti-CD44 monoclonal antibody improves cellular uptake and antitumor efficacy of liposomal doxorubicin. J. Control. Release 2015, 220, 275-286. [CrossRef]

53. Tzircotis, G.; Thorne, R.F.; Isacke, C.M. Chemotaxis towards hyaluronan is dependent on CD44 expression and modulated by cell type variation in CD44-hyaluronan binding. J. Cell Sci. 2005, 118, 5119-5128. [CrossRef] [PubMed]

54. Lee, E.; Lim, S.-J. The association of increased lung resistance protein expression with acquired etoposide resistance in human H460 lung cancer cell lines. Arch. Pharm. Res. 2006, 29, 1018-1023. [CrossRef] [PubMed]

55. Patel, N.R.; Pattni, B.S.; Abouzeid, A.H.; Torchilin, V.P. Nanopreparations to overcome multidrug resistance in cancer. Adv. Drug Deliv. Rev. 2013, 65, 1748-1762. [CrossRef] [PubMed] 